\title{
Impact of Exercise Modalities on Peripheral and Central Components of Cardiorespiratory Capacity in Heart Transplantation Patients: A Systematic Review and Meta-Analysis
}

\author{
Natália Turri-Silva ${ }^{1,2,3}$, Francisco Valdez Santos ${ }^{1,4,+}$, Wanessa Camilly Caldas Rodrigues ${ }^{1}$, Josuelir Silva Freire ${ }^{1}$, \\ Lawrence C. Cahalin ${ }^{5}$, Kenneth Verboven ${ }^{2}{ }^{\circledR}$, João Luiz Quaglioti Durigan ${ }^{1}$, Dominique Hansen ${ }^{2,5, *}$ \\ and Gerson Cipriano, Jr. ${ }^{1,+}$ \\ 1 Health and Technologies in Health Sciences Program, University of Brasilia, Brasilia 72220-275, Brazil; \\ natalia.turridasilva@uhasselt.be (N.T.-S.); limasvaldez03@gmail.com (F.V.S.); \\ wanessacamilly@gmail.com (W.C.C.R.); josuelir.sf@gmail.com (J.S.F.); joaodurigan@gmail.com (J.L.Q.D.); \\ ciprianeft@gmail.com (G.C.J.) \\ 2 REVAL/BIOMED—Rehabilitation Research Center, Faculty of Rehabilitation Sciences, Hasselt University, \\ 3590 Diepenbeek, Belgium; kenneth.verboven@uhasselt.be \\ 3 Heart Centre Hasselt, Jessa Hospital, 3500 Hasselt, Belgium \\ 4 Department of Education and Training in Oncology, Cancer Institute of São Paulo, São Paulo 03102-002, Brazil \\ 5 Department of Physical Therapy, University of Miami Miller School of Medicine, \\ Coral Gables, FL 33167-3495, USA; 1.cahalin@gmail.com \\ * Correspondence: dominique.hansen@uhasselt.be \\ + Shared first author.
}

check for updates

Citation: Turri-Silva, N.; Santos, F.V.; Rodrigues, W.C.C.; Freire, J.S.;

Cahalin, L.C.; Verboven, K.;

Quaglioti Durigan, J.L.; Hansen, D.;

Cipriano, G., Jr. Impact of Exercise

Modalities on Peripheral and Central

Components of Cardiorespiratory

Capacity in Heart Transplantation

Patients: A Systematic Review and

Meta-Analysis. Medicina 2022, 58, 32.

https://doi.org/10.3390/

medicina58010032

Academic Editor: Martin Grapow

Received: 28 October 2021

Accepted: 15 December 2021

Published: 24 December 2021

Publisher's Note: MDPI stays neutral with regard to jurisdictional claims in published maps and institutional affiliations.

Copyright: (C) 2021 by the authors. Licensee MDPI, Basel, Switzerland. This article is an open access article distributed under the terms and conditions of the Creative Commons Attribution (CC BY) license (https:// creativecommons.org/licenses/by/ $4.0 /)$.

\begin{abstract}
Background and Objectives: To analyze the effects of aerobic, resistance, and combined training on peripheral and central components related to cardiorespiratory capacity after HTx. Materials and Methods: No time restriction was applied for study inclusion. MEDLINE/PubMed; EMBASE, CENTRAL, and PEDro databases were investigated. Studies reporting heart transplanted patients older than 19 years following aerobic, resistance, and combined training according. The outcomes included: $\mathrm{V}^{\prime} \mathrm{O}_{2}$ peak, $\mathrm{VE} / \mathrm{V}^{\prime} \mathrm{CO}_{2}$ slope, heart rate (HR peak), systolic and diastolic blood pressure (SBP and DBP peak), maximum repetition test(1RM), sit-to-stand test, and flow-mediated dilation (FMD). The studies were selected by consensus. Four hundred ninety-two studies initially met the selection criteria. Cochrane handbook was used for abstracting data and assessing data quality and validity. Independent extraction by two observers was applied. Results: Isolated aerobic training leads to a greater increase in $\mathrm{V}^{\prime} \mathrm{O}_{2}$ peak than combined training compared to the control group $(p<0.001, \mathrm{I} 2=0 \%)$. However, no significant differences were found in the subgroup comparison $(p=0.19, \mathrm{I} 2=42.1 \%)$. HR peak increased similarly after aerobic and combined training. High-intensity interval training (HIIT) was better than moderate continuous intensity to increase the $\mathrm{V}^{\prime} \mathrm{O}_{2}$ after long term in HTx. Still, there is scarce evidence of HIIT on muscle strength and FMD. No change on $\mathrm{VE} / \mathrm{V}^{\prime} \mathrm{CO}_{2}$ slope, FMD, and SBP, DBP peak. 1RM and the sit-to-stand test increased after resistance training $(p<0.001, \mathrm{I} 2=70 \%)$ and CT $(p<0.001, \mathrm{I} 2=0 \%)$ when compared to control. Conclusions: Aerobic and combined training effectively improve $\mathrm{VO}_{2}$ peak and muscle strength, respectively. HIIT seems the better choice for cardiorespiratory capacity improvements. More studies are needed to examine the impact of training modalities on $\mathrm{VE} / \mathrm{V}^{\prime} \mathrm{CO}_{2}$ slope and FMD.
\end{abstract}

Keywords: exercise; heart transplantation; prognosis; exercise tolerance

\section{Introduction}

Despite the improvements in pharmaceutical and resynchronization treatments and even considering the advent of the left-ventricular assist device [1], heart transplantation (HTx) remains a notable treatment for advanced heart failure [2-4]. HTx gives a new life opportunity for such patients improving peak oxygen uptake $\left(\mathrm{V}^{\prime} \mathrm{O}_{2}\right.$ peak) [5-7], a well-recognized prognostic variable assessed via cardiopulmonary exercise test and a 
gold standard approach to measure sources of exercise limitation in all contest of heart failure. Peak oxygen uptake is still reduced in HTx in comparison to healthy age-matched individuals $[8,9]$. Nonetheless, to reach a better prognosis after $\mathrm{HTx}$, a $\mathrm{V}^{\prime} \mathrm{O}_{2}$ peak increase is wanted [9].

Reduced exercise capacity is associated with cardiac, vascular, and muscular limitations post-HTx [10]. Cardiovascular limitation involves chronotropic incompetence with higher resting heart rate and reduced peak heart rate $[10,11]$. Peripheral limitations involve vascular endothelial dysfunction by flow-mediated dilation [FMD] reductions [10,12-17] and losses in lean mass affecting muscle strength and exercise intolerance post HTx [10]. The immunosuppressive treatment also promotes muscle and $\mathrm{V}^{\prime} \mathrm{O}_{2}$ peak reduction $[10,18]$, and peak systolic and diastolic blood pressure increase due to its vasoconstrictor effect [19]. Peak heart rate and systolic blood pressure are also affected by the sympathetic reduction due to the removal of the sinus node [19].

Clinical practice guidelines recommend exercise training for HTx to increase exercise capacity [19]. Regarding exercise training modalities, aerobic training (AT) increases $\mathrm{V}^{\prime} \mathrm{O}_{2}$ peak, reduces both systolic and diastolic blood pressure, and perceived exertion in HTx patients [20]. Resistance training (RT) added to aerobic training improves muscle strength and $\mathrm{V}^{\prime} \mathrm{O}_{2}$ peak in HTx [21]. Reductions in blood pressure and increments in muscle strength can significantly influence the increase in exercise capacity. $\mathrm{VE} / \mathrm{V}^{\prime} \mathrm{CO}_{2}$ slope can stratify the survival rate being an important parameter post-HTx.

There is bolding evidence regarding exercise program's effects post-HTx [9]; however, the pivotal understanding about the preferred exercise prescription for exercise capacity (modality and intensity) remain unexplored. This review evaluates and compares the isolated and combined effect of the aerobic training (AT) and resistance training (RT) on cardiorespiratory components $\left(\mathrm{V}^{\prime} \mathrm{O}_{2}\right.$ peak and $\mathrm{VE} / \mathrm{V}^{\prime} \mathrm{CO}_{2}$ slope), cardiovascular components (HR peak, SBP peak, and DBP peak), and peripheral components (FMD and muscle strength) post-HTx. We hypothesized that aerobic training with moderate intensity is more favorable post-HTx.

\section{Materials and Methods}

\subsection{Searches}

We followed the recommendations described in the preferred reporting items for systematic reviews and meta-analyses (PRISMA) and Cochrane Handbook [22]. The protocol was registered in the PROSPERO database (https: / / www.crd.york.ac.uk/prospero/ display_record.php?RecordID =59911, accessed on 20 December 2021) under number: CRD42017059911. The systematic review was performed in MEDLINE/PubMed; EMBASE, CENTRAL, and PEDro. The search strategy can be checked on Electronic Supplementary Materials.

\subsection{Study Inclusion and Exclusion Criteria}

Eligibility criteria: (1) Randomized Clinical Trials (RCTs) with or without a cross-over strategy, (2) participants $\geq 19$ years old, who received HTx, (3) studies that described the aerobic training (AT), resistance training (RT), or the combination of both (CT), at any intensity; and (4) studies that compared physical training through exercise with a control group without exercise or comparisons between modalities or training intensities. Language inclusion: English, French, Dutch, and Portuguese. We excluded studies without comparison groups and with aquatic exercise.

\subsection{Types of Interventions and Outcomes}

We considered isolated AT, RT or CT performed at a hospital, outpatient, or homebased setting. We considered exercise interventions post-HTx with the following characteristics: (1) Frequency: at least two days per week; (2) Duration: at least eight weeks and (3) Intensity: at least $50 \%$ of maximum heart rate (HRmax) or $50 \%$ of $\mathrm{V}^{\prime} \mathrm{O}_{2}$ peak for aerobic exercise and $40 \%$ of one maximum repetition (1RM) for resistance exercise. The 
clinical outcomes of the studies should have included at least one of the following measures: peak oxygen uptake $\left(\mathrm{V}^{\prime} \mathrm{O}_{2}\right.$ peak, $\left.\mathrm{mL}^{*} \mathrm{~kg}^{-1}{ }^{*} \mathrm{~min}^{-1}\right), \mathrm{VE} / \mathrm{V}^{\prime} \mathrm{CO}_{2}$ slope, peak systolic and diastolic blood pressure (SBP peak and DBP peak, mmHg), peak heart rate (HR peak, bpm), muscle strength (1RM and sitting to stand test) and flow-mediated dilation (FMD, \%).

\subsection{Data Extraction, Synthesis, and Presentation}

Type of study, population, interventions (including the type of exercise, intensity, frequency, duration, and modality), comparison and outcomes, risk of bias, and results were extracted. A single researcher performed the data extraction procedure, and a second researcher scrutinized it. All recommendation for a systematic review with metanalysis was followed according to Cochrane Handbook version 6.0 [22]. All analyses were conducted using Review Manager (RevMan) [Computer program]. Version 5.4. The Cochrane Collaboration, 2020. More details about data synthesis description and analysis are on Electronic Supplementary Materials.

Electronic Supplementary Materials also includes Quality of the trials, Risk of bias assessment, and Summary of Findings Table with quality of evidence.

\section{Results}

\subsection{Selection, Evaluation of Studies, and Quality Assessment}

The initial search identified 2712 studies and the present systematic review included 15 studies based on the inclusion criteria, and 13 studies considered for metanalysis. The reasons for exclusion are in Figure 1.

Nine studies involving AT [23-31], three studies involving CT [32-34], and two involving RT $[35,36]$ were included. Only two studies compared exercise intensities [30,31] and one study compared home-based versus hospital-based intervention [37]. All the other studies included an intervention group compared to a non-exercise control group.

\subsection{Studies Included in the Systematic Review}

The publication period of the included studies ranged from 1998 to 2019, involving a total of 453 patients undergoing HTx with 407 (72\%) males, with a mean age of 51 years in the intervention group and 47 years in the control group. Two studies reported only the RT protocol and three studies, included combined training (resistance + aerobic training). Surprisingly, only one of those CT studies reported a detailed prescription of the RT [30]. Also, only two studies presented a comparison between aerobic intensities, high-intensity interval training (HIIT) vs. moderate continuous training (MCT-AE) [31,38], and one study compared hospital-based versus home-based exercise following the same training prescription. Table 1 illustrates the studies summary. PEDRo score is included in Table 1 to provide the quality score from each study individually (widely used in the rehabilitation field). 

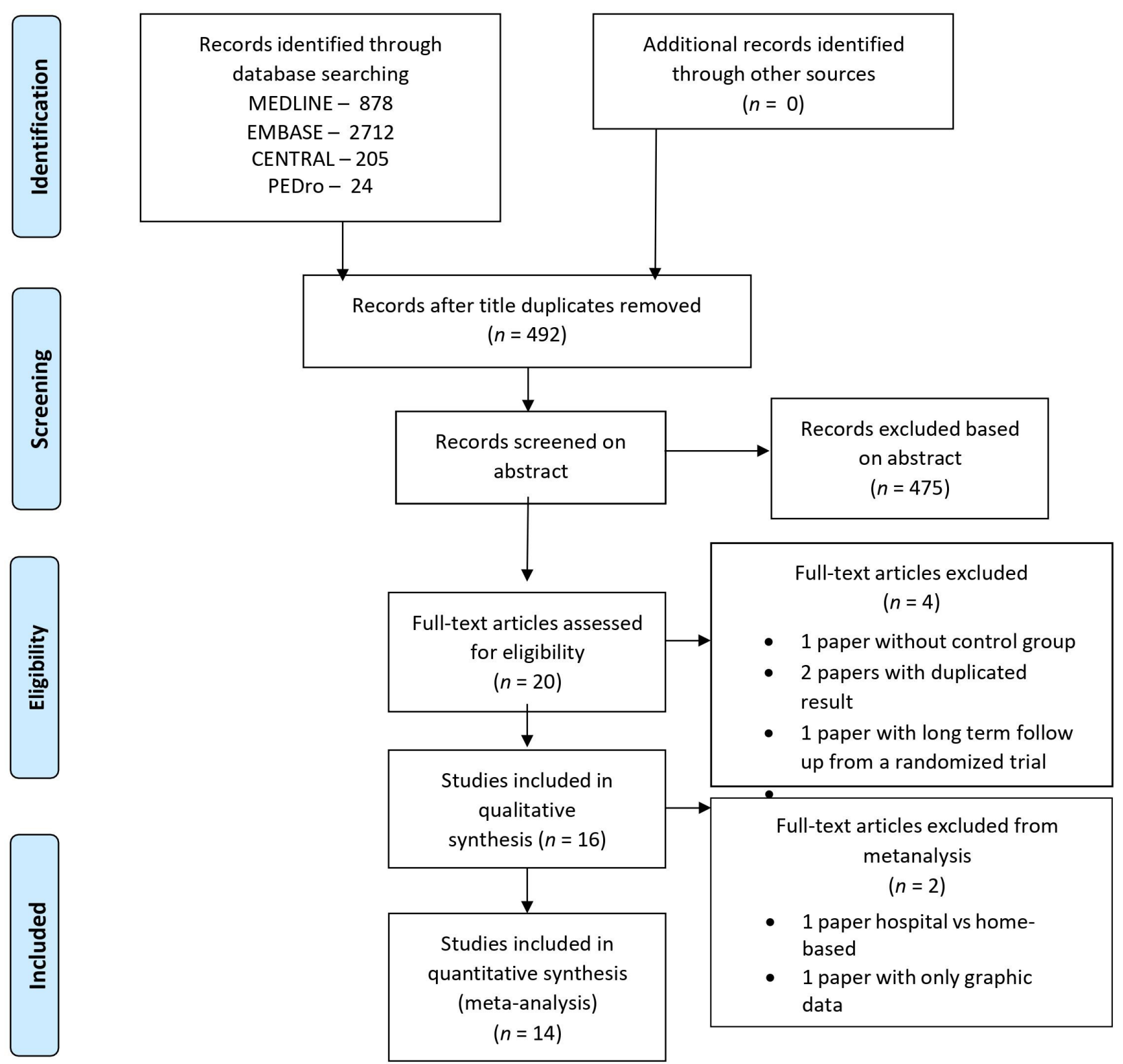

Figure 1. PRISMA Flowchart of the procedures for the selection of articles inserted in the final analysis. 
Table 1. Description of studies included in the systematic review.

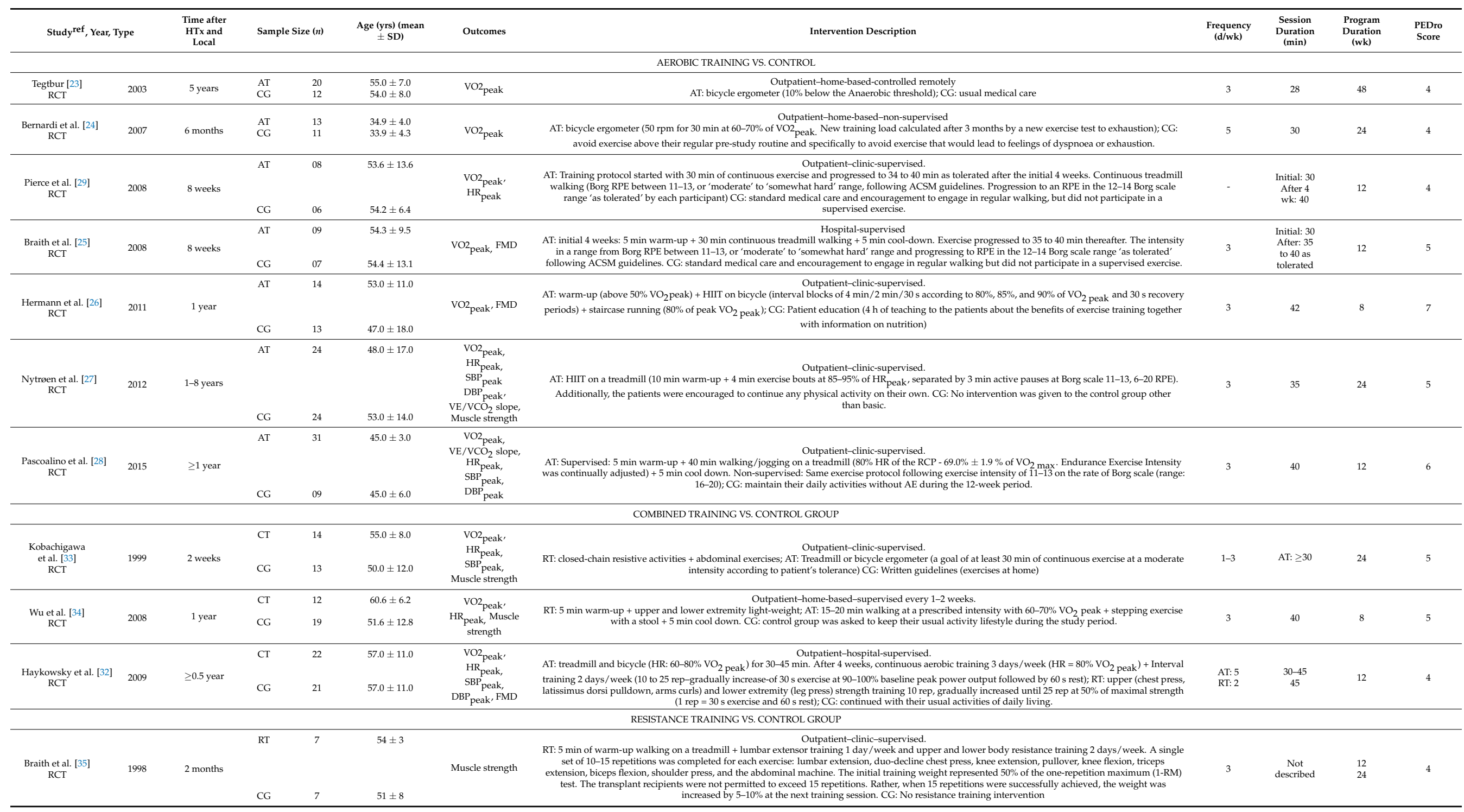


Table 1. Cont.

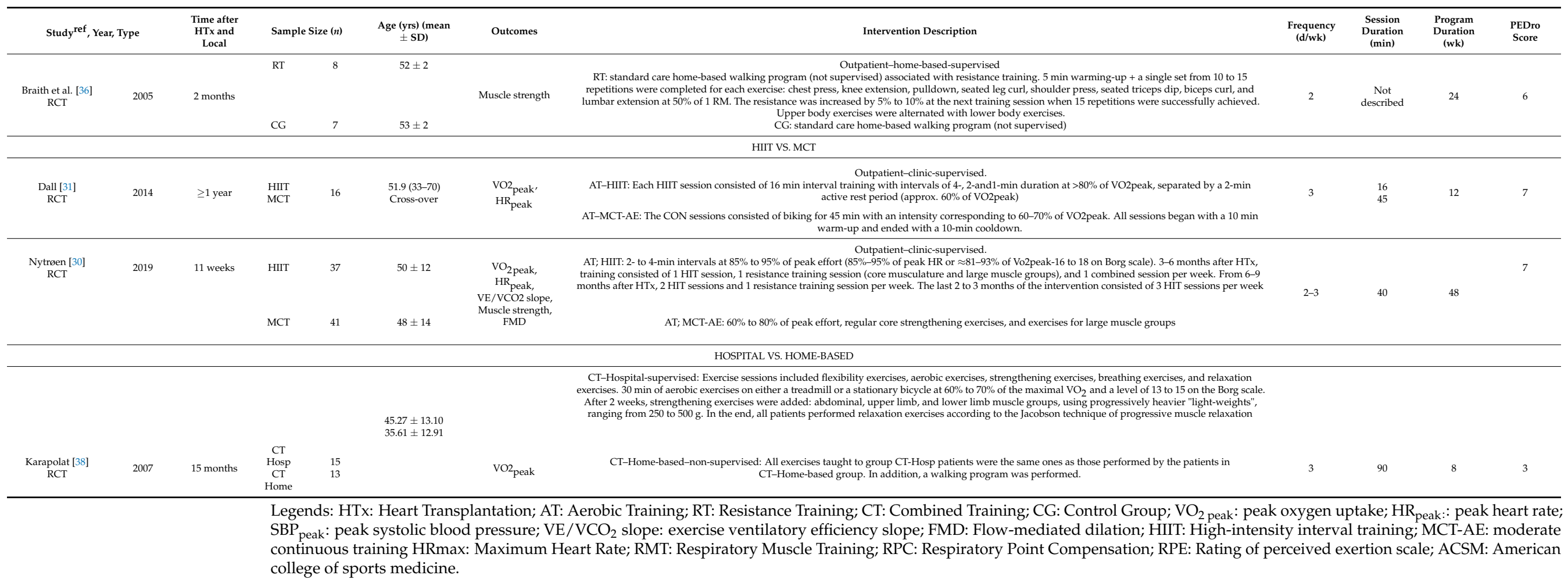


Regarding the AE, the average frequency was 3 days per week, with a duration of $35 \pm 5$ min per session and a protocol duration of $18 \pm 11$ weeks. Among the AE modalities, with MCT-AE, the intensity ranged from $60-80 \%$ of $\mathrm{V}^{\prime} \mathrm{O}_{2}$ peak $[24,28,32], 10 \%$ below the anaerobic threshold [23], or Borg RPE between 11-14 [25,29].

One study utilized the higher patient's tolerance sustained for $30 \mathrm{~min}$ [33]. Four studies applied HIIT $[26,27,30,31]$ and one applied HIIT alternating with continuous training [32]. HIIT intensities ranged from $80-90 \%$ of the $\mathrm{V}^{\prime} \mathrm{O}_{2}$ peak, 80-95\% of the HR peak, or $90-100 \%[32,39]$ of the baseline peak power output. Interval duration varied from $30 \mathrm{~s}$ to $4 \mathrm{~min}$, alternated by low-intensity phases with an intensity ranging from 11 to 13 [27] according to the BORG scale or a recovery rest phase [26,32,39]. Recovery duration varied from $30 \mathrm{~s}$ to $3 \mathrm{~min}$, while some studies adopted passive rest recovery.

Heterogeneity was low for $\mathrm{V}^{\prime} \mathrm{O}_{2}$ peak, slope $\mathrm{VE} / \mathrm{V}^{\prime} \mathrm{CO}_{2}$, and sit-to-stand test $\left(\mathrm{I}^{2}<50 \%\right)$. SBP, DBP and HR peak, FMD, and 1RM indicated high heterogeneity $\left(\mathrm{I}^{2}>50 \%\right)$. No study reported adverse effects. The agreement level between the reviewers, by Kappa coefficient, was 0.95 (95\% CI: 0.75 to 1.03. 3 Exercise effects on peak oxygen consumption).

Exercise training significantly improve $\mathrm{V}^{\prime} \mathrm{O}_{2}$ peak considering all pooled data ( 9 studies, $n=294$ patients) with a mean difference $[\mathrm{MD}]=2.84,95 \% \mathrm{CI}: 2.10$ to $3.58, \mathrm{~mL} \cdot \mathrm{kg}^{-1} \cdot \mathrm{min}^{-1}$, $\mathrm{I} 2=0 \%$. However, greater $\mathrm{V}^{\prime} \mathrm{O}_{2}$ peak were found for isolated $\mathrm{AE}(6$ studies, $n=187$ patients) $\mathrm{MD}=3.36,95 \% \mathrm{CI}: 2.29$ to $4.44 \mathrm{~mL} \cdot \mathrm{kg}^{-1} \cdot \mathrm{min}^{-1}, \mathrm{I}^{2}=0 \%$ than combined intervention (CT) (3 studies, $n=107$ patients) $\mathrm{MD}=2.37,95 \% \mathrm{CI}: 1.36$ to $3.39 \mathrm{~mL} \cdot \mathrm{kg} \cdot \mathrm{min}^{-1}, \mathrm{I} 2=27 \%$ (Figure 2A) when compared to control group.

A greater $\mathrm{V}^{\prime} \mathrm{O}_{2}$ peak increase were found for HIIT-AE (2 studies, $n=75$ patients), $\mathrm{MD}=4.43,95 \% \mathrm{CI}: 0.54$ to $8.31 \mathrm{~mL} \cdot \mathrm{kg} \cdot \mathrm{min}^{-1}, \mathrm{I}^{2}=0 \%$ ) than MCT-AE (4 studies, $n=112$ patients), $\mathrm{MD}=3.23,95 \% \mathrm{CI}: 1.94$ to $4.52 \mathrm{~mL} \cdot \mathrm{kg} \cdot \mathrm{min}^{-1}, \mathrm{I}^{2}=0 \%$, (Figure $2 \mathrm{~B}$ ) when both were compared to a control group. The HIIT superiority over MCT-AE was directly demonstrated when compared one versus another ( 2 studies, $n=110$ patients) with a mean difference $\mathrm{MD}=1.96$, 95\% CI: 0.99 to $2.93 \mathrm{~mL} \mathrm{~kg}^{-1} \mathrm{~min}^{-1}, \mathrm{I}^{2}=0 \%$ (Figure $2 \mathrm{C}$ ).

\subsection{Exercise Effects on Peak Heart Rate}

The analysis of peak heart rate was separated according to time post-HTx: de novo and long therm. Comparing the pooled effect analysis of aerobic and combined training versus control group after long term post $\operatorname{HTx}(\geq 1$ year), jointly both training induced a slightly favorable effect in HR peak (4 studies, $n=164$ patients), MD $=8.10,95 \% \mathrm{CI}$ : 1.98 to $14.22 \mathrm{bpm}, \mathrm{I}^{2}=87 \%, p=0.009$, with no subgroup differences $(p=0.12)$ (Figure 3 ). 
A

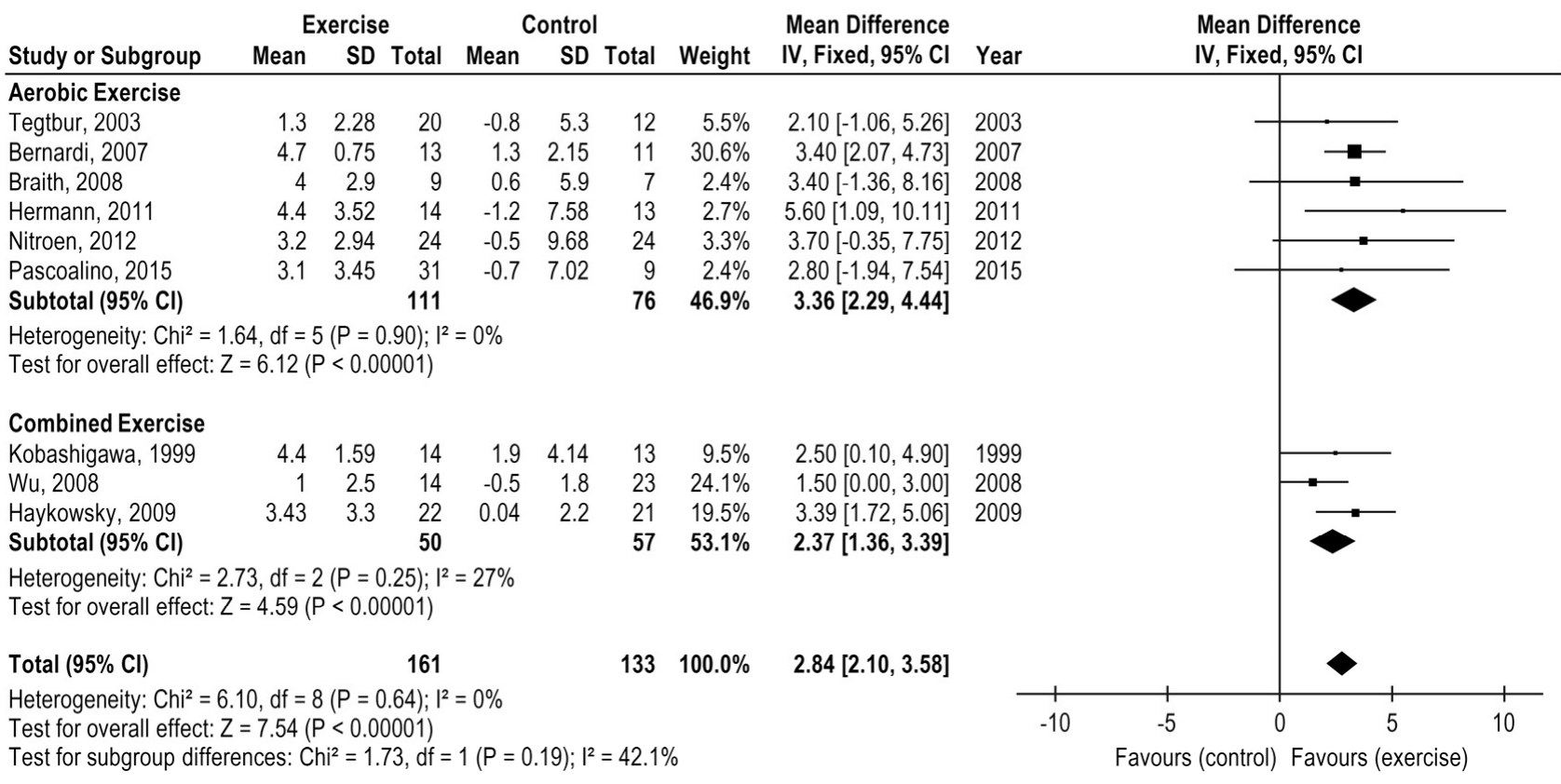

B

\begin{tabular}{lrrrrrrrrr} 
& \multicolumn{2}{c}{ Exercise } & \multicolumn{3}{c}{ Control } & \multicolumn{3}{c}{ Mean Difference } \\
Study or Subgroup & Mean & SD & Total & Mean & SD Total & Weight & IV, Fixed, 95\% Cl & Yea \\
\hline MCT-AE & & & & & & & & & \\
Bernardi, 2007 & 4.68 & 1.39 & 13 & 1.27 & 2.15 & 11 & $68.7 \%$ & $3.41[1.93,4.89]$ & 2007 \\
Braith, 2008 & 4 & 6.98 & 7 & 0.6 & 5.9 & 9 & $3.6 \%$ & $3.40[-3.05,9.85]$ & 2008 \\
Pascoalino, 2015 & 2.1 & 10.07 & 31 & -0.7 & 2.34 & 9 & $10.1 \%$ & $2.80[-1.06,6.66]$ & 2015 \\
Tegtbur, 2003 & 1.3 & 5.93 & 20 & -0.8 & 6.36 & 12 & $7.6 \%$ & $2.10[-2.34,6.54]$ & 2003 \\
Subtotal (95\% CI) & & & 71 & & & 41 & $\mathbf{9 0 . 0 \%}$ & $3.23[1.94,4.52]$
\end{tabular}

Heterogeneity: $\mathrm{Chi}^{2}=0.36, \mathrm{df}=3(\mathrm{P}=0.95) ; \mathrm{I}^{2}=0 \%$

Test for overall effect: $Z=4.90(P<0.00001)$

HIIT

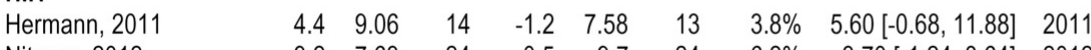

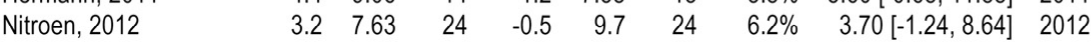

$\begin{array}{lllll}\text { Subtotal }(95 \% \mathrm{Cl}) & 38 & 37 & 10.0 \% & 4.43[0.54,8.31]\end{array}$

Heterogeneity: $\mathrm{Chi}^{2}=0.22, \mathrm{df}=1(\mathrm{P}=0.64) ; \mathrm{I}^{2}=0 \%$

Test for overall effect: $Z=2.23(P=0.03)$

Total $(95 \% \mathrm{Cl})$

109

$78 \quad 100.0 \% \quad 3.35[2.12,4.57]$

Heterogeneity: Chi $^{2}=0.90, \mathrm{df}=5(P=0.97) ;\left.\right|^{2}=0 \%$

Test for overall effect: $Z=5.36(P<0.00001)$

Test for subgroup differences: Chi $^{2}=0.33, d f=1(P=0.57) ; 1^{2}=0 \%$

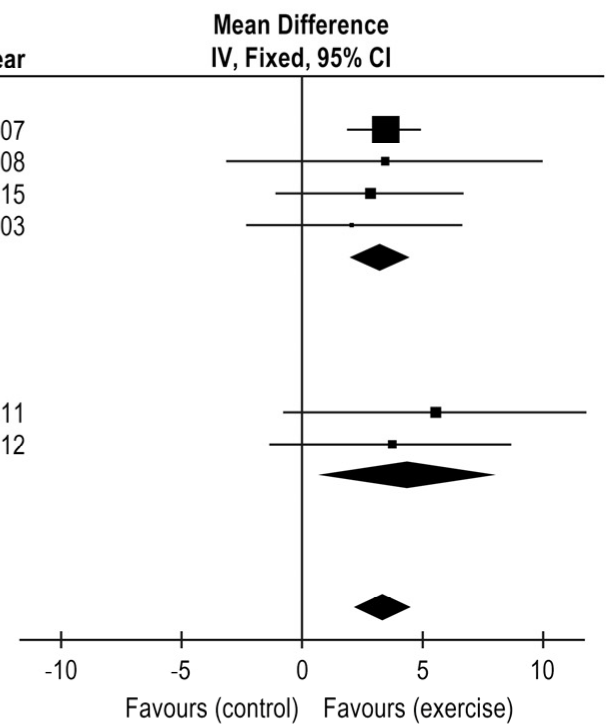

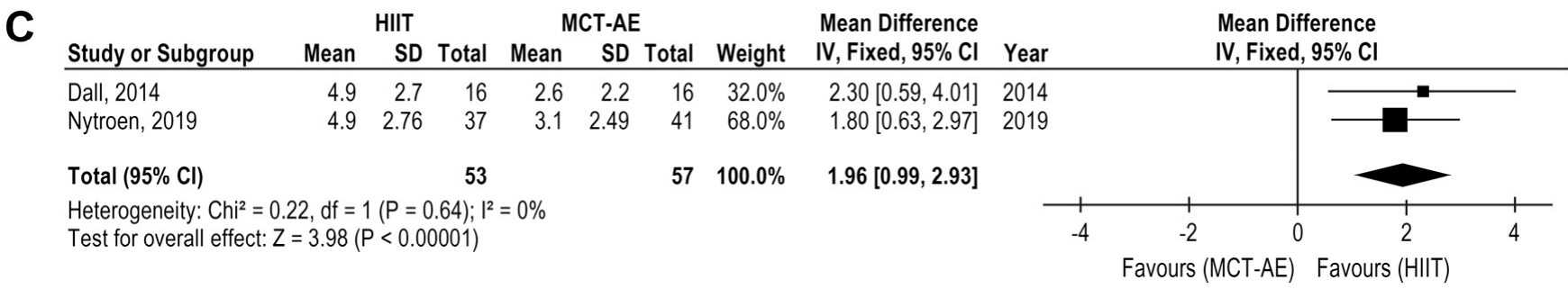

Figure 2. Impact of exercise training on $\mathrm{V}^{\prime} \mathrm{O}_{2}$ peak (mL.kg.min) in HTx (A) exercise versus the control group (B) moderate continuous training and high-intensity training versus the control group (C) moderate continuous training versus high-intensity interval training. 


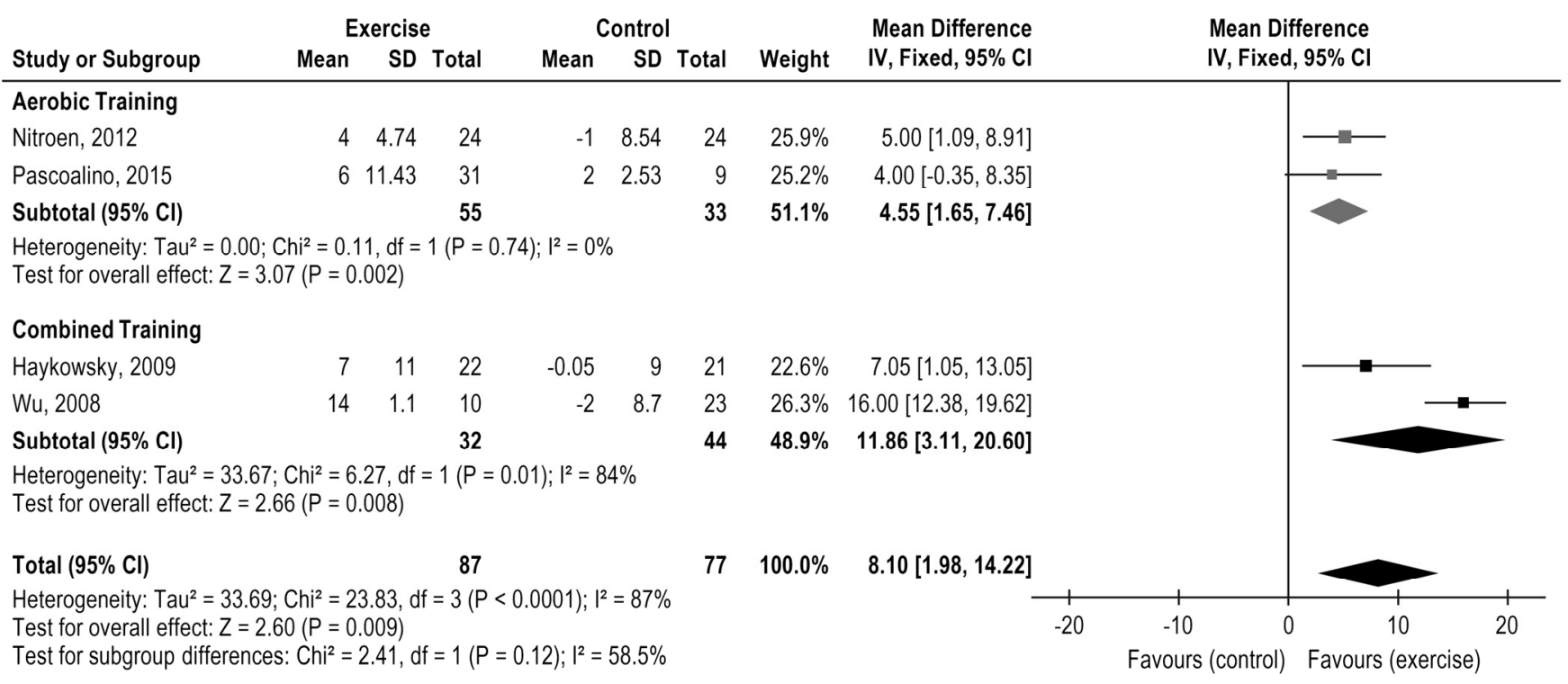

Figure 3. Impact of exercise training on Heart Rate peak (bpm) in HTx: exercise versus the control group.

Two studies have explored exercise versus control in de novo HTx ( $<1$ year) and both aerobic [29] and combined training [33] did not indicate improvement on HR peak. Two studies compared HIIT versus moderate continuous training in de novo [30] and long term [31] post-HTx and the delta comparison indicated better results for HIIT only in long term post-HTx $(p=0.027)$ [31].

\subsection{Exercise Effects on Peak Systolic and Diastolic Blood Pressure}

Aerobic and combined exercise modalities comparison did not demonstrate changes in SBP peak post-HTx (4 studies, $n=158$ patients), $\mathrm{MD}=7.87,95 \% \mathrm{CI}:-18.64$ to 34.39, $\mathrm{mmHg}, \mathrm{I}^{2}=87 \%$ (Figure $4 \mathrm{~A}$ ) and DBP peak (3 studies, $n=131$ ), $\mathrm{MD}=-6.90,95 \% \mathrm{CI}$ : -14.81 to $1.02, \mathrm{mmHg}^{2} \mathrm{I}^{2}=72 \%$ (Figure $4 \mathrm{~B}$ ) although the separated analysis demonstrated a superior effect on DBP peak reduction from the aerobic exercise compared with a control ( 2 studies, $n=135$ ), $\mathrm{MD}=-11.0,95 \% \mathrm{CI}:-16.03$ to $-5.97 \mathrm{mmHg}, \mathrm{I}^{2}=0 \%$ (Figure $4 \mathrm{~B}$ ).

\subsection{Exercise Effects on $\mathrm{VE} / \mathrm{V}^{\prime} \mathrm{CO}_{2}$ Slope}

Only two studies had reported this outcome comparing exercise versus control group in HTx patients, both involving aerobic training $[27,28]$. The exercise treatment did not demonstrate any difference on $\mathrm{VE} / \mathrm{V}^{\prime} \mathrm{CO}_{2}$ slope ( 2 studies, $n=88$ patients), $\mathrm{MD}=0.77$, $95 \%$ CI: -0.18 to $1.72, \mathrm{I}^{2}=18 \%, p=0.11$ (Figures 5 and 6 ). One study explored the comparison between HIIT vs moderate continuous training, not indicating any differences between them $(n=78), \mathrm{MD}=-1.6(-5.2$ to 2.0$), p=0.375$ [30].

\subsection{Exercise Effects on Flow-Mediated Dilation}

Three studies compared the exercise treatment with control in HTx patients. Exercise training did not demonstrate positive effect on FMD (3 studies, $n=86$ patients), $\mathrm{MD}=3.48 \%, 95 \% \mathrm{CI}:-0.29$ to $7.25 \%, p=0.07)$. However, the studies presented a high heterogeneity $\left(\mathrm{I}^{2}=80 \%\right)$-Figure 6 . From those included studies, one study applied MCTAE [25], one study applied CT [32], and one HIIT [26]. Only HIIT [28] presented an expressive improvement in FMD. However, a subgroup analysis was not possible due to the small number of studies in each exercise modality. Nytroen 2019 compared HIIT vs moderate continuous training and did not indicated differences for this parameter between modalities $(n=78), \mathrm{MD}=-1.5(-4$ to 0.9$), p=0.208$ [30]. 


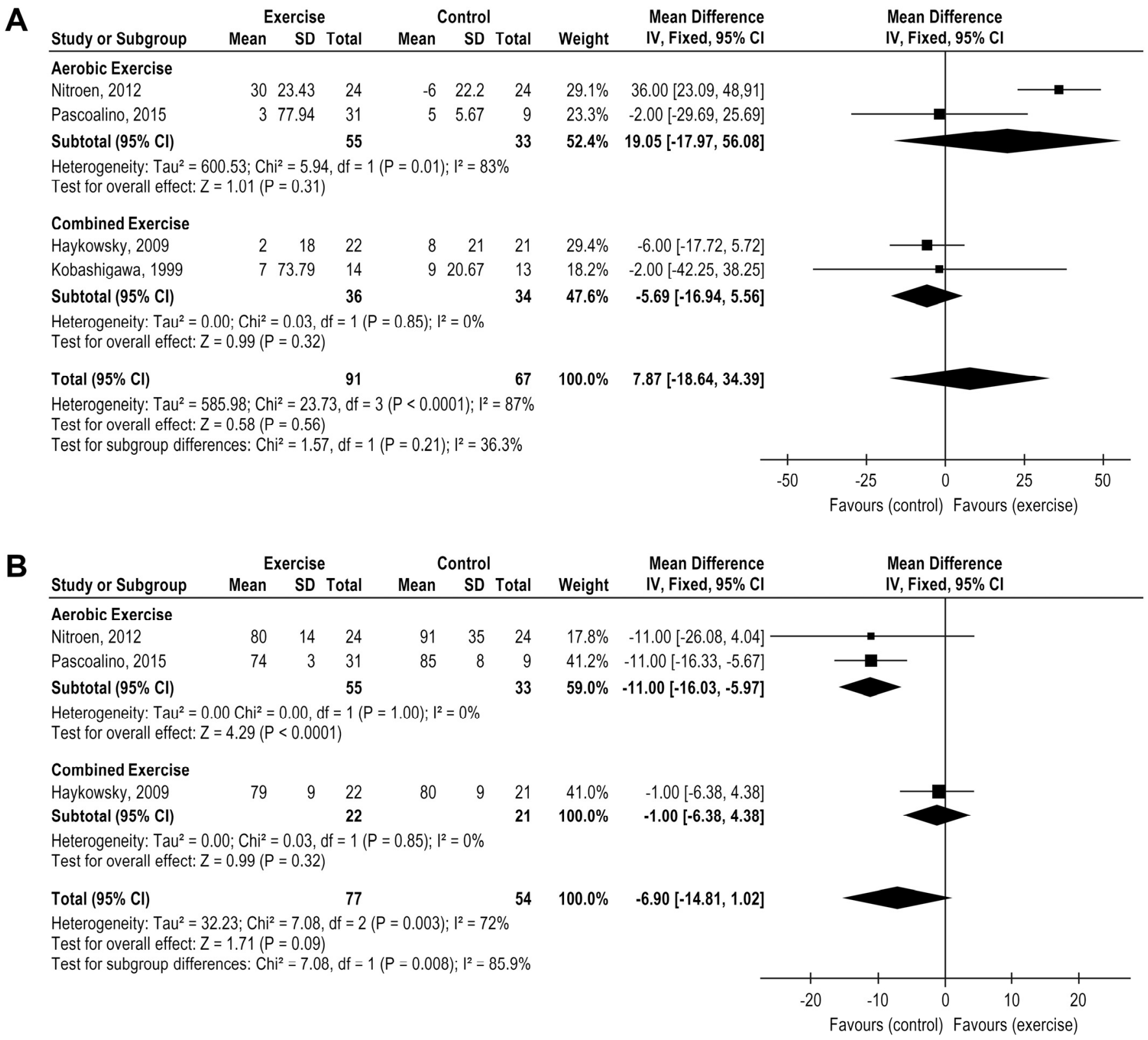

Figure 4. Impact of exercise training on blood pressure ( $\mathrm{mmHg}$ ) in HTx (A) exercise versus control group for systolic blood pressure (B) exercise versus control group for diastolic blood pressure.

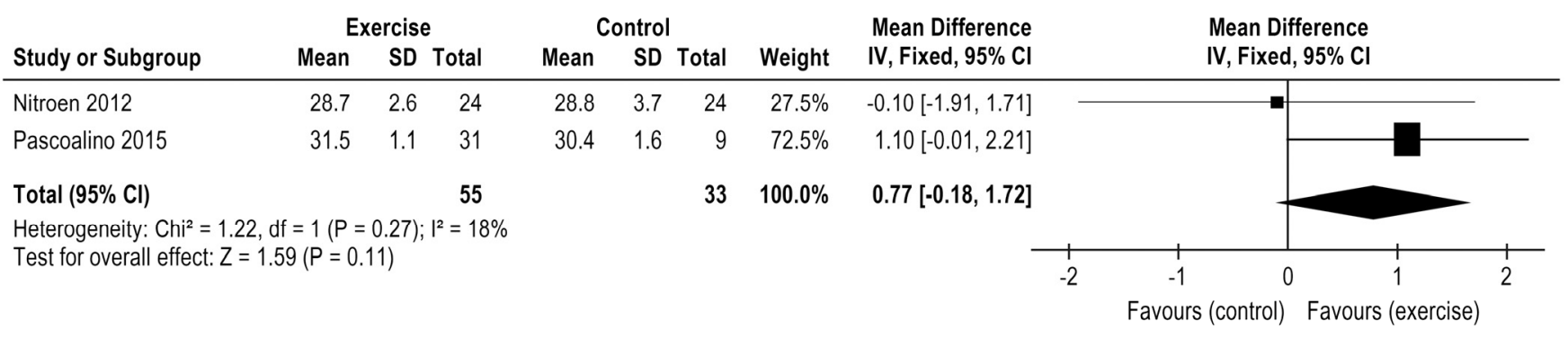

Figure 5. Impact of exercise training on $\mathrm{VE} / \mathrm{V}^{\prime} \mathrm{CO}_{2}$ slope in $\mathrm{HTx}$. 


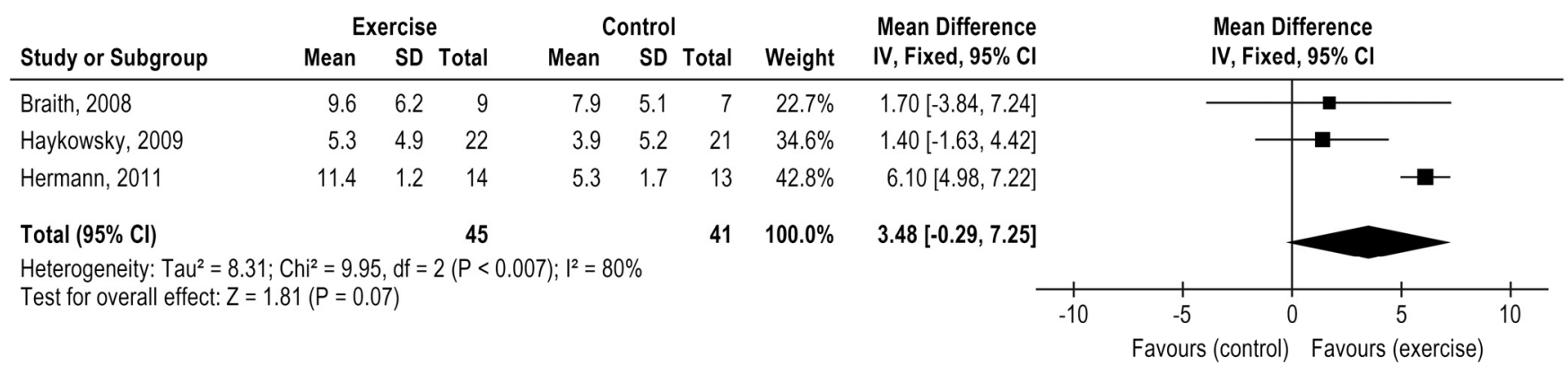

Figure 6. Impact of exercise training on flow-mediated dilation in HTx.

\subsection{Exercise Effects on Muscle Strength}

Six studies analyzed the exercise impact on muscle strength, but two were not included in the metanalysis forest plots due to different muscle strength assessments (Isokinetic and isotonic evaluations). Two studies evaluated the maximum repetition test (1RM) and two evaluated the sit-to-stand test. Isolated resistance training (RT) was associated with a significant improvement in the $1 \mathrm{RM}$ for both chest press and leg extension movements, $\mathrm{MD}=35.50 \mathrm{Kg}, 95 \% \mathrm{CI}: 19.42$ to $51.59, \mathrm{I}^{2}=70, p<0.0001$ ) (Figure 7A) while the other two studies involving combined training showed increases on the sit-to-stand test, MD: 5.54, $95 \%$ CI 3.07 to $8.01 ; \mathrm{I}^{2}=0 \%$ (Figure 7B). Isokinetic and isotonic evaluations not included in the metanalysis forest plots, also suggested an increase in muscle strength after CT and AT, respectively $[27,34]$.

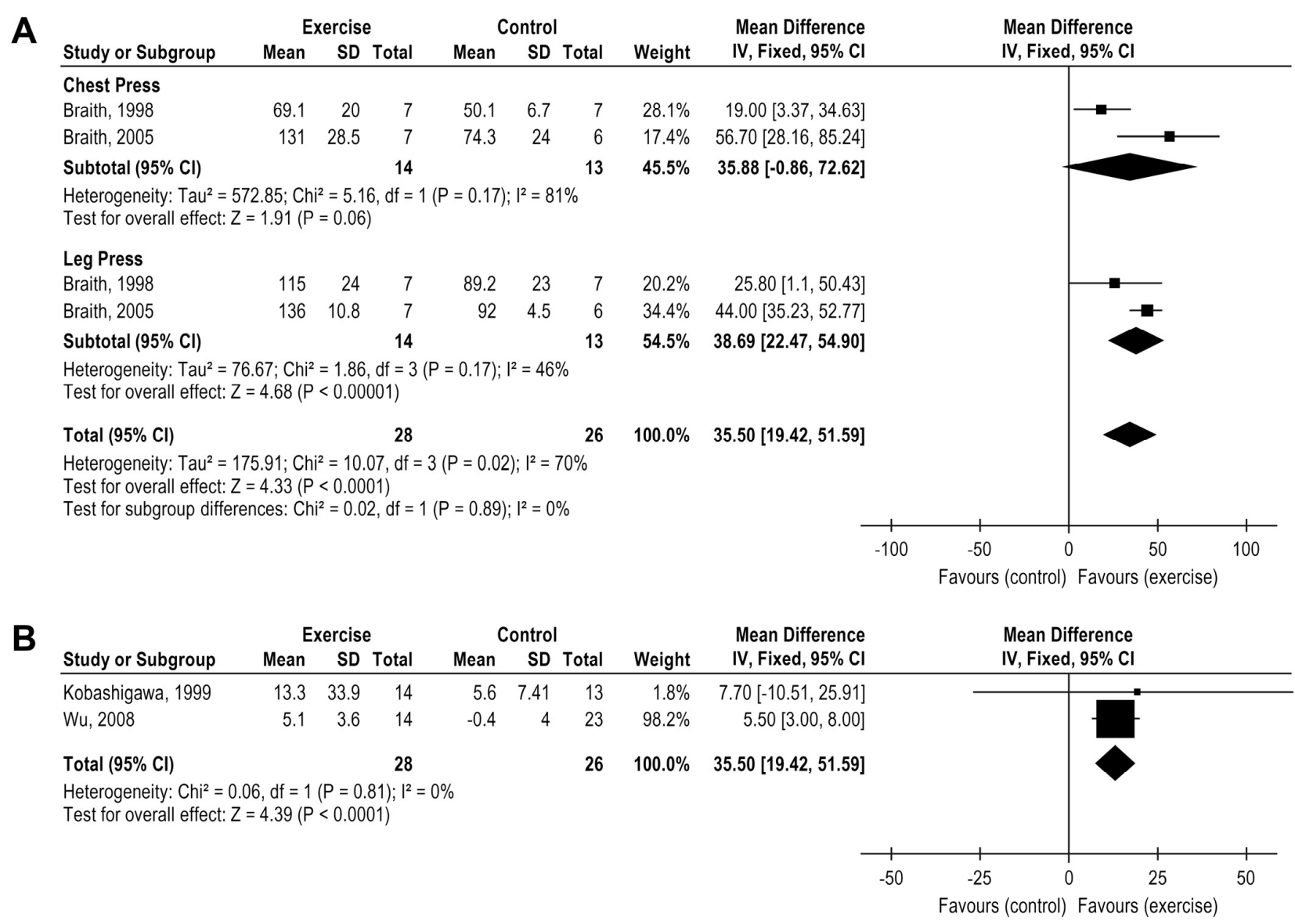

Figure 7. Impact of resistance training on muscle strength in HTx (A) 1 maximum repetition test (B) sit-to-stand test. 


\section{Discussion}

The novelty of this meta-analysis is the analysis of different exercise modalities and intensities in clinical outcomes related to cardiorespiratory capacity after HTx, strengthening information about training prescription for clinical practice. A superior effect of aerobic training to improve $\mathrm{V}^{\prime} \mathrm{O}_{2}$ peak in $\mathrm{HTx}$ patients was demonstrated with a moderate level of certainty of evidence. Interesting, high-intensity interval training (HIIT) demonstrated a higher effect on the $\mathrm{V}^{\prime} \mathrm{O}_{2}$ peak than moderate continuous training (MCT-AE) with no adverse effect [30,31].

Considering the low level of certainty of the evidence, resistance exercise training (RT) led to improvements in muscle strength. The skeletal muscle weakness, vasodilatory capacity impairment, and muscle capillary density reduction are the main peripheral factors related to exercise capacity reductions after HTx and partially explain the $\mathrm{V}^{\prime} \mathrm{O}_{2}$ peak impairment [40]. Nytrøen et al. pointed to the association between muscular deconditioning and $\mathrm{V}^{\prime} \mathrm{O}_{2}$ peak reduction [27], recognizing the peripheral limitations in HTx patients. Peripheral adaptation such as mitochondrial volume density, oxidative enzyme capacity, and the percentage of type 1 muscle fibers distribution increase, are associated with the cardiorespiratory capacity increase $[10,36,41]$. These results indicate RT, isolated, or in combination with $\mathrm{AT}$, increases muscle strength and attenuates $\mathrm{V}^{\prime} \mathrm{O}_{2}$ peak impairment postHTx.

There was no evidence that exercise affect DBP and SBP peak in HTx $[27,28,33]$ and like HR peak, all indicated a very low level of certainty of evidence. HR peak increased after all training modalities, especially after AE. Compared to MCT-AE, a higher increase in HR peak occurred after HIIT with a moderate level of certainty of evidence. However, the magnitude seems not equivalent to the exercise capacity improvement $[6,42,43]$, possibly due to the chronotropic incompetence [24,44]. Autonomic nervous system improvement may explain it $[24,43,44]$. The average increase of SBP peak should be $50 \%$ of the resting value and an insufficient increase has been associated with left ventricular systolic dysfunction [45]. Nevertheless, the relationship between SBP response and $\mathrm{V}^{\prime} \mathrm{O}_{2}$ peak is unclear.

The absence of improvements after CT [33], HIIT [27,46], or MCT-AE [47] on LV end-diastolic or end-systolic volume, stroke volume, or ejection fraction after HTx [10] contributes to the rationale that the improvements in peak $\mathrm{V}^{\prime} \mathrm{O}_{2}$ seem not only related to central (cardiac) adaptations [10].

A healthy endothelium function positively impacts exercise-induced vasodilation capacity, an essential part of the maintenance of adequate $\mathrm{V}^{\prime} \mathrm{O}_{2}$ during exercise. FMD increase positively influences $\mathrm{V}^{\prime} \mathrm{O} 2$ peak in healthy individuals [48-50], coronary heart disease, hypertension, and heart failure [51-54]. Inversely, endothelial dysfunction is associated with plaque progression and a lower peak $\mathrm{V}^{\prime} \mathrm{O} 2$ post-HTx $[55,56]$.

Exercise training was not associated with FMD benefits [25,26,32] (very low level of certainty of the evidence), but an expressive improvement was when HIIT was compared to a control group [26]. More studies are needed, but recognizing that endothelial dysfunction predicts cardiac allograft vasculopathy [14], HIIT seems a promising approach post-HTx. The unique study that compared HIIT vs. moderate continuous training did not indicate differences between those modalities, although the statistical difference was seen only within the HIIT group. Although an endothelial function recovery occurs post-HTx [57], peripheral endothelial dysfunction remains after 1 to 13 years [58]. The primary mechanism of the endothelial dysfunction post-HTx relates to cyclosporin therapy [10,57]. Exercise training can counteract it by enhancing nitric oxide (NO) production $[48,49]$.

According to the two included studies and with a very low level of evidence, there is no effect on $\mathrm{VE} / \mathrm{V}^{\prime} \mathrm{CO}_{2}$ slope after exercise training post-HTx when compared to a control group. Nytroen, 2019 when comparing HIIT vs. moderate continuous training also did not reveal any difference between modalities [30]. $\mathrm{VE} / \mathrm{V}^{\prime} \mathrm{CO}_{2}$ slope is a strong independent predictor of mortality in HF patients [59] as accurate as $\mathrm{V}^{\prime} \mathrm{O}_{2}$ peak for HTx. Although the $\mathrm{VO}_{2}$ peak is related to mortality like $\mathrm{VE} / \mathrm{VCO}_{2}$ slope, none of the included studies addressed morbidity or mortality rates after their intervention or control period. The 
positive association between $\mathrm{VE} / \mathrm{V}^{\prime} \mathrm{CO}_{2}$ slope reduction and functional capacity improvement was identified in $40 \%$ of the patients post-HTx, even five years later [60]. VE/ $/ \mathrm{V}^{\prime} \mathrm{CO}_{2}$ slope increase has been associated with peripheral factors, such as muscle deconditioning, peripheral oxygen transport problems, and type IIb-muscle-fiber increased, leading to a primary lactic acidosis during exercise demanding high ventilatory response [60]. In our meta-analysis, only aerobic training (27) (28) explored $\mathrm{VE} / \mathrm{V}^{\prime} \mathrm{CO}_{2}$ slope post-HTx.

The small number of studies available and the low level of certainty of evidence from many outcomes is the major limitation of this systematic review with meta-analysis. Additionally, the lack of studies reporting comparison between modalities has limited the results of exercise training post-HTx. More research is required, mainly for the outcomes $\mathrm{VE} / \mathrm{V}^{\prime} \mathrm{CO}_{2}$ slope and FMD. In addition, the absence of an increase in heart rate peak after exercise training may have been influenced by the poor autonomic response due to cardiac denervation. Another limitation is the absence of information regarding the age mismatch between donors and recipients of the included studies. Finally, it is also a problem that patients with left ventricular assistant systems before transplantation often present good exercise tolerance and are not scrutinized from those without left ventricular assistant systems [61] which could influence the final meta-analysis results. However, even considering the limitations, this review is important to demonstrate the state of the art on training prescription in HTx, revealing the need for new clinical trials with higher quality.

\section{Conclusions}

Cardiac rehabilitation is essential after HTx to improve the training performance of the patients. From this review, aerobic training seems the best training modality after HTx, mainly high-intensity interval training with the biggest effect on peak oxygen consumption 7265677. Isolated resistance training or combined training improve muscle strength. More studies are needed.

Supplementary Materials: The following are available online at https:/ /www.mdpi.com/article/ 10.3390 /medicina58010032/s1, Figure S1: Risk of bias assessed via Rob 2 tool, Figure S2: Summary of Findings Tables with quality of evidence for exercise training compared to control, Figure S3: Summary of Findings Tables with quality of evidence for HIIT compared to moderate continous training, Table S1: Physiotherapy Evidence Database (PEDro) scores for each of the 12 included studies in the metanalysis.

Author Contributions: W.C.C.R., J.S.F., N.T.-S. and G.C.J. contributed substantially to the conception and design of the study; N.T.-S., F.V.S., W.C.C.R. and J.S.F. contributed substantially to the acquisition of data; N.T.-S., F.V.S. and G.C.J. contributed substantially to the analysis and interpretation; K.V. and G.C.J. provided a double-check analysis for Rob2 and Grade score; N.T.-S., F.V.S., K.V., L.C.C., J.L.Q.D., D.H. and G.C.J. drafted or provided critical revision of the article; G.C.J. and D.H. provided final approval of the version of the review. All authors have read and agreed to the published version of the manuscript.

Funding: This study was financed in part by the Coordenação de Aperfeiçoamento de Pessoal de Nível Superior-federal grant support from Brazil (CAPES DS)-Finance Code 001 and the Special Research Fund for Bilateral scientific cooperation BOF-BILA-Hasselt University grant support (Belgium). Both grants support was assigned to Natália Turri-Silva.

Institutional Review Board Statement: Not applicable.

Informed Consent Statement: Not applicable.

Data Availability Statement: The data presented in this study are available on request from the corresponding author.

Conflicts of Interest: All authors from this manuscript have no conflicts of interest or financial ties to disclose. 


\section{References}

1. Theochari, C.A.; Michalopoulos, G.; Oikonomou, E.K.; Giannopoulos, S.; Doulamis, I.P.; Villela, M.A.; Kokkinidis, D.G. Heart transplantation versus left ventricular assist devices as destination therapy or bridge to transplantation for 1-year mortality: A systematic review and meta-analysis. Ann. Cardiothorac. Surg. 2018, 7, 3-11. [CrossRef]

2. Yusen, R.D.; Edwards, L.B.; Dipchand, A.I.; Goldfarb, S.B.; Kucheryavaya, A.Y.; Levvey, B.J.; Lund, L.H.; Meiser, B.; Rossano, J.W.; Stehlik, J. The Registry of the International Society for Heart and Lung Transplantation: Thirty-third Adult Heart Transplantation Report-2016; Focus Theme: Primary Diagnostic Indications for Transplant. J. Heart Lung Transpl. 2016, 35, 1158-1169. [CrossRef] [PubMed]

3. Jessup, M.; Drazner, M.H.; Book, W.; Cleveland, J.C.; Dauber, I.; Farkas, S.; Ginwalla, M.; Katz, J.N.; Kirkwood, P.; Kittleson, M.M.; et al. 2017 ACC/AHA/HFSA/ISHLT/ACP Advanced Training Statement on Advanced Heart Failure and Transplant Cardiology (Revision of the ACCF/AHA/ACP/HFSA/ISHLT 2010 Clinical Competence Statement on Management of Patients with Advanced Heart Failure and Cardiac Trans. J. Am. Coll. Cardiol. 2017, 69, 2977-3001. [CrossRef] [PubMed]

4. Di Nora, C.; Livi, U. Heart transplantation in cardiac storage diseases: Data on Fabry disease and cardiac amyloidosis. Curr. Opin. Organ Transplant. 2020, 25, 211-217. [CrossRef]

5. Habedank, D.; Ewert, R.; Hummel, M.; Wensel, R.; Hetzer, R.; Anker, S.D. Changes in exercise capacity, ventilation, and body weight following heart transplantation. Eur. J. Heart Fail. 2007, 9, 310-316. [CrossRef]

6. Carter, R.; Al-Rawas, O.; Stevenson, A.; McDonagh, T.; Stevenson, R. Exercise Responses Following Heart Transplantation: 5 Year Follow-Up. Scott. Med. J. 2006, 51, 6-14. [CrossRef]

7. McDonagh, T.A.; Metra, M.; Adamo, M.G.R.; Baumbach, A.; Bo, M.B.H.; Butler, J.; Celutkiene, J.; Chioncel, O.C.J.G.; Coats, A.J.S.; Crespo-Leiro, M.G.; et al. 2021 ESC Guidelines for the diagnosis and treatment of acute and chronic heart failure. Eur. Heart J. 2021, 42, 3599-3726. [CrossRef]

8. Savin, W.M.; Haskell, W.L.; Schroeder, J.S.; Stinson, E.B. Cardiorespiratory responses of cardiac transplant patients to graded, symptom-limited exercise. Circulation 1980, 62, 55-60. [CrossRef] [PubMed]

9. Anderson, L.; Nguyen, T.T.; Dall, C.H.; Burgess, L.; Bridges, C.; Taylor, R.S. Exercise-based cardiac rehabilitation in heart transplant recipients. Cochrane Database Syst. Rev. 2017, 2017, CD012264. [CrossRef]

10. Tucker, W.J.; Beaudry, R.I.; Samuel, T.J.; Nelson, M.D.; Halle, M.; Baggish, A.L. Performance Limitations in Heart Transplant Recipients. Exerc. Sport Sci. Rev. 2018, 46, 144-151. [CrossRef] [PubMed]

11. Notarius, C.F.; Levy, R.D.; Tully, A.; Fitchett, D.; Magder, S. Cardiac versus noncardiac limits to exercise after heart transplantation. Am. Heart J. 1998, 135, 339-348. [CrossRef]

12. Hollenberg, S.M.; Klein, L.W.; Parrillo, J.E.; Scherer, M.; Burns, D.; Tamburro, P.; Oberoi, M.; Johnson, M.R.; Costanzo, M.R. Coronary Endothelial Dysfunction After Heart Transplantation Predicts Allograft Vasculopathy and Cardiac Death. Circulation 2001, 104, 3091-3096. [CrossRef]

13. Przybylowski, P.; Koc-Zorawska, E.; Malyszko, J.; Mysliwiec, M. Renalase and Endothelial Dysfunction in Heart Transplant Recipients. Transplant. Proc. 2013, 45, 394-396. [CrossRef]

14. Stehlik, J.; Edwards, L.B.; Kucheryavaya, A.Y.; Benden, C.; Christie, J.; Dipchand, A.I.; Dobbels, F.; Kirk, R.; Rahmel, A.O.; Hertz, M.I. The Registry of the International Society for Heart and Lung Transplantation: 29th Official Adult Heart Transplant Report-2012. J. Heart Lung Transpl. 2012, 31, 1052-1064. [CrossRef] [PubMed]

15. Tepperman, E.; Ramzy, D.; Prodger, J.; Sheshgiri, R.; Badiwala, M.; Ross, H. Surgical biology for the clinician: Vascular effects of immunosuppression. Can. J. Surg. 2010, 53, 57-63.

16. Holm, T.; Aukrust, P.; Andreassen, A.K.; Ueland, T.; Brosstad, F.; Froland, S.S.; Simonsen, S.; Gullestad, L. Peripheral endothelial dysfunction in heart transplant recipients: Possible role of proinflammatory cytokines. Clin. Transplant. 2000, 14, 218-225. [CrossRef]

17. Montero, D. The association of cardiorespiratory fitness with endothelial or smooth muscle vasodilator function. Eur. J. Prev. Cardiol. 2014, 22, 1200-1211. [CrossRef] [PubMed]

18. Jendzjowsky, N.G.; Tomczak, C.R.; Lawrance, R.; Taylor, D.A.; Tymchak, W.J.; Riess, K.J.; Warburton, D.E.R.; Haykowsky, M.J. Impaired pulmonary oxygen uptake kinetics and reduced peak aerobic power during small muscle mass exercise in heart transplant recipients. J. Appl. Physiol. 2007, 103, 1722-1727. [CrossRef] [PubMed]

19. Costanzo, M.R.; Dipchand, A.; Starling, R.; Anderson, A.; Chan, M.; Desai, S.; Fedson, S.; Fisher, P.; Gonzales-Stawinski, G.; Martinelli, L.; et al. The International Society of Heart and Lung Transplantation Guidelines for the care of heart transplant recipients. J. Heart Lung Transplant. 2010, 29, 914-956. [CrossRef] [PubMed]

20. Hsieh, P.-L.; Wu, Y.-T.; Chao, W.-J. Effects of Exercise Training in Heart Transplant Recipients: A Meta-Analysis. Cardiology 2011, 120, 27-35. [CrossRef]

21. Mandic, S.; Tymchak, W.; Kim, D.; Daub, B.; Quinney, H.A.; Taylor, D.; Al-Kurtass, S.; Haykowsky, M.J. Effects of aerobic or aerobic and resistance training on cardiorespiratory and skeletal muscle function in heart failure: A randomized controlled pilot trial. Clin. Rehabil. 2009, 23, 207-216. [CrossRef]

22. Higgins, J.P.; Thomas, J.; Chandler, J.; Cumpston, M.; Li, T.; Page, M.J.; Welch, V.A. (Eds.) Cochrane Handbook for Systematic Reviews of Interventions Version 6.0. Available online: www.training.cochrane.org/handbook (accessed on 18 December 2021).

23. Tegtbur, U.; Busse, M.W.; Jung, K.; Markofsky, A.; Machold, H.; Brinkmeier, U.; Haverich, A.; Pethig, K. Phase III Rehabilitation nach Herztransplantation; Springer: Berlin/Heidelberg, Germany, 2003; Volume 92, pp. 908-915. [CrossRef] 
24. Bernardi, L.; Radaelli, A.; Passino, C.; Falcone, C.; Auguadro, C.; Martinelli, L.; Rinaldi, M.; Viganò, M.; Finardi, G. Effects of physical training on cardiovascular control after heart transplantation. Int. J. Cardiol. 2007, 118, 356-362. [CrossRef]

25. Braith, R.W.; Schofield, R.S.; Hill, J.A.; Casey, D.; Pierce, G.L. Exercise Training Attenuates Progressive Decline in Brachial Artery Reactivity in Heart Transplant Recipients. J. Heart Lung Transplant. 2008, 27, 52-59. [CrossRef] [PubMed]

26. Hermann, T.S.; Dall, C.H.; Christensen, S.B.; Goetze, J.P.; Prescott, E.; Gustafsson, F. Effect of High Intensity Exercise on Peak Oxygen Uptake and Endothelial Function in Long-Term Heart Transplant Recipients. Arab. Archaeol. Epigr. 2011, 11, 536-541. [CrossRef]

27. Nytrøen, K.; Rustad, L.A.; Aukrust, P.; Ueland, T.; Hallén, J.; Holm, I.; Rolid, K.; Lekva, T.; Fiane, A.E.; Amlie, J.P.; et al. High-Intensity Interval Training Improves Peak Oxygen Uptake and Muscular Exercise Capacity in Heart Transplant Recipients. Arab. Archaeol. Epigr. 2012, 12, 3134-3142. [CrossRef]

28. Pascoalino, L.N.; Ciolac, E.G.; Tavares, A.C.; Castro, R.E.; Ayub-Ferreira, S.M.; Bacal, F.; Issa, V.S.; Bocchi, E.A.; Guimarães, G.V. Exercise training improves ambulatory blood pressure but not arterial stiffness in heart transplant recipients. J. Heart Lung Transplant. 2015, 34, 693-700. [CrossRef]

29. Pierce, G.L.; Schofield, R.S.; Casey, D.; Hamlin, S.A.; Hill, J.A.; Braith, R.W. Effects of exercise training on forearm and calf vasodilation and proinflammatory markers in recent heart transplant recipients: A pilot study. Eur. J. Cardiovasc. Prev. Rehabil. 2008, 15, 10-18. [CrossRef] [PubMed]

30. Nytrøen, K.; Rolid, K.; Andreassen, A.K.; Yardley, M.; Gude, E.; Dahle, D.O.; Bjørkelund, E.; Authen, A.R.; Grov, I.; Wigh, J.P.; et al. Effect of High-Intensity Interval Training in De Novo Heart Transplant Recipients in Scandinavia. Circulation 2019, 139, $2198-2211$. [CrossRef]

31. Dall, C.H.; Snoer, M.; Christensen, S.; Monk-Hansen, T.; Frederiksen, M.; Gustafsson, F.; Langberg, H.; Prescott, E. Effect of High-Intensity Training Versus Moderate Training on Peak Oxygen Uptake and Chronotropic Response in Heart Transplant Recipients: A Randomized Crossover Trial. Arab. Archaeol. Epigr. 2014, 14, 2391-2399. [CrossRef]

32. Haykowsky, M.; Taylor, D.; Kim, D.; Tymchak, W. Exercise Training Improves Aerobic Capacity and Skeletal Muscle Function in Heart Transplant Recipients. Arab. Archaeol. Epigr. 2009, 9, 734-739. [CrossRef] [PubMed]

33. Kobashigawa, J.A.; Leaf, D.A.; Lee, N.; Gleeson, M.P.; Liu, H.; Hamilton, M.A.; Moriguchi, J.D.; Kawata, N.; Einhorn, K.; Herlihy, E.; et al. A Controlled Trial of Exercise Rehabilitation after Heart Transplantation. N. Engl. J. Med. 1999, 340, $272-277$. [CrossRef]

34. Wu, Y.-T.; Chien, C.-L.; Chou, N.-K.; Wang, S.-S.; Lai, J.-S.; Wu, Y.-W. Efficacy of a Home-Based Exercise Program for Orthotopic Heart Transplant Recipients. Cardiology 2008, 111, 87-93. [CrossRef]

35. Braith, R.; Welsch, M.; Mills, R.; Keller, J.; Pollock, M. Resistance exercise prevents glucocorticoid-induced myopathy in heart transplant recipients. Med. Sci. Sport Exerc. 1998, 30, 483-489. [CrossRef]

36. Braith, R.W.; Magyari, P.M.; Pierce, G.L.; Edwards, D.G.; Hill, J.A.; White, L.J.; Aranda, J.M. Effect of Resistance Exercise on Skeletal Muscle Myopathy in Heart Transplant Recipients. Am. J. Cardiol. 2005, 95, 1192-1198. [CrossRef] [PubMed]

37. Karapolat, H.; Demir, E.; Bozkaya, Y.T.; Eyigor, S.; Nalbantgil, S.; Durmaz, B.; Zoghi, M. Comparison of hospital-based versus home-based exercise training in patients with heart failure: Effects on functional capacity, quality of life, psychological symptoms, and hemodynamic parameters. Clin. Res. Cardiol. 2009, 98, 635-642. [CrossRef]

38. Karapolat, H.; Eyigör, S.; Zoghi, M.; Yagdi, T.; Nalbangil, S.; Durmaz, B. Comparison of Hospital-Supervised Exercise Versus Home-Based Exercise in Patients After Orthotopic Heart Transplantation: Effects on Functional Capacity, Quality of Life, and Psychological Symptoms. Transplant. Proc. 2007, 39, 1586-1588. [CrossRef]

39. Monk-Hansen, T.; Dall, C.H.; Christensen, S.B.; Snoer, M.; Gustafsson, F.; Rasmusen, H.; Prescott, E. Interval training does not modulate diastolic function in heart transplant recipients. Scand. Cardiovasc. J. 2014, 48, 91-98. [CrossRef]

40. Braith, R.W.; Limacher, M.C.; Leggett, S.H.; Pollock, M.L. Skeletal muscle strength in heart transplant recipients. J. Heart Lung Transplant. 1993, 12, 1018-1023. [PubMed]

41. Lampert, E.; Mettauer, B.; Hoppeler, H.; Charloux, A.; Charpentier, A.; Lonsdorfer, J. Skeletal muscle response to short endurance training in heart transplant recipients. J. Am. Coll. Cardiol. 1998, 32, 420-426. [CrossRef]

42. Nytrøen, K.; Rustad, L.A.; Gude, E.; Hallén, J.; Fiane, A.E.; Rolid, K.; Holm, I.; Aakhus, S.; Gullestad, L. Muscular exercise capacity and body fat predict VO2peak in heart transplant recipients. Eur. J. Prev. Cardiol. 2012, 21, 21-29. [CrossRef] [PubMed]

43. Nytrøen, K.; Myers, J.; Chan, K.N.; Geiran, O.R.; Gullestad, L. Chronotropic Responses to Exercise in Heart Transplant Recipients. Am. J. Phys. Med. Rehabil. 2011, 90, 579-588. [CrossRef] [PubMed]

44. Bengel, F.M.; Ueberfuhr, P.; Schiepel, N.; Nekolla, S.G.; Reichart, B.; Schwaiger, M. Effect of Sympathetic Reinnervation on Cardiac Performance after Heart Transplantation. N. Engl. J. Med. 2001, 345, 731-738. [CrossRef]

45. Salles, A.F.; Machado, C.V.; Cordovil, A.; Leite, W.A.; Moisés, V.A.; de Almeida, D.R. A elevação da pressão arterial sistólica durante o teste ergométrico após transplante cardíaco: Correlação com o quadro clínico e a função ventricular avaliada pela ecocardiografia sob estresse com dobutamina. Arq. Bras. Cardiol. 2006, 87, 628-633. [CrossRef]

46. Geny, B.; Saini, J.; Mettauer, B.; Lampert, E.; Piquard, F.; Follenius, M.; Epailly, E.; Schnedecker, B.; Eisenmann, B.; Haberey, P.; et al. Effect of short-term endurance training on exercise capacity, haemodynamics and atrial natriuretic peptide secretion in heart transplant recipients. Graefe's Arch. Clin. Exp. Ophthalmol. 1996, 73, 259-266. [CrossRef]

47. Kavanagh, T.; Yacoub, M.H.; Mertens, D.J.; Kennedy, J.; Campbell, R.B.; Sawyer, P. Cardiorespiratory responses to exercise training after orthotopic cardiac transplantation. Circulation 1988, 77, 162-171. [CrossRef] 
48. Franzoni, F.; Ghiadoni, L.; Galetta, F.; Plantinga, Y.; Lubrano, V.; Huang, Y.; Salvetti, A.; Regoli, F.; Taddei, S.; Santoro, G. Physical activity, plasma antioxidant capacity, and endothelium-dependent vasodilation in young and older men. Am. J. Hypertens. 2005, 18, 510-516. [CrossRef] [PubMed]

49. Tinken, T.M.; Thijssen, D.H.J.; Black, M.A.A.; Cable, N.; Green, D.J. Time course of change in vasodilator function and capacity in response to exercise training in humans. J. Physiol. 2008, 586, 5003-5012. [CrossRef] [PubMed]

50. Buscemi, S.; Canino, B.; Batsis, J.A.; Buscemi, C.; Calandrino, V.; Mattina, A.; Arnone, M.; Caimi, G.; Cerasola, G.; Verga, S. Relationships between maximal oxygen uptake and endothelial function in healthy male adults: A preliminary study. Acta Diabetol. 2010, 50, 135-141. [CrossRef] [PubMed]

51. Linke, A.; Schoene, N.; Gielen, S.; Hofer, J.; Erbs, S.; Schuler, G.; Hambrecht, R. Endothelial dysfunction in patients with chronic heart failure: Systemic effects of lower-limb exercise training. J. Am. Coll. Cardiol. 2001, 37, 392-397. [CrossRef]

52. Gokce, N.; Vita, J.A.; Bader, D.S.; Sherman, D.L.; Hunter, L.M.; Holbrook, M.; O’Malley, C.; Keaney, J.F., Jr.; Balady, G.J. Effect of exercise on upper and lower extremity endothelial function in patients with coronary artery disease. Am. J. Cardiol. 2002, 90, 124-127. [CrossRef]

53. Walsh, J.; Bilsborough, W.; Maiorana, A.; Best, M.; O’Driscoll, G.J.; Taylor, R.R.; Green, D.J. Exercise training improves conduit vessel function in patients with coronary artery disease. J. Appl. Physiol. 2003, 95, 20-25. [CrossRef] [PubMed]

54. Higashi, Y.; Sasaki, S.; Sasaki, N.; Nakagawa, K.; Ueda, T.; Yoshimizu, A.; Kurisu, S.; Matsuura, H.; Kajiyama, G.; Oshima, T. Daily Aerobic Exercise Improves Reactive Hyperemia in Patients with Essential Hypertension. Hypertension 1999, 33, 591-597. [CrossRef] [PubMed]

55. Gullestad, L.; Myers, J.; Edvardsen, T.; Kjekshus, J.; Geiran, O.; Simonsen, S. Predictors of exercise capacity and the impact of angiographic coronary artery disease in heart transplant recipients. Am. Heart J. 2004, 147, 49-54. [CrossRef]

56. Watanabe, T.; Seguchi, O.; Nishimura, K.; Yanase, M.; Sato, T.; Sunami, H.; Nakajima, S.; Hisamatsu, E.; Sato, T.; Kuroda, K.; et al. Is Brachial Flow-Mediated Dilation the Predictor of Development of Cardiac Allograft Vasculopathy in Recipients with Heart Transplantation? Circulation 2014, 130, 11585. [CrossRef]

57. Cuppoletti, A.; Sitges, M.; Pérez Villa, F.; Orús, J.; Magriñá, J.; Roig, E. Impairment in forearm endothelium-dependent vasodilation after heart transplantation. Transplant. Proc. 2003, 35, 2011-2013. [CrossRef]

58. Roig, E.; Cuppoletti, A.; Masotti, M.; Kianco, R.; Vallejos, I.; Sitges, M. Assessment of Peripheral Endothelial-Dependent Vasodilatation Within the First Year After Heart Transplantation. J. Heart Lung Transplant. 2009, 28, 299-304. [CrossRef]

59. Ferreira, A.M.; Tabet, J.-Y.; Frankenstein, L.; Metra, M.; Mendes, M.; Zugck, C.; Beauvais, F.; Cohen-Solal, A. Ventilatory Efficiency and the Selection of Patients for Heart Transplantation. Circ. Heart Fail. 2010, 3, 378-386. [CrossRef]

60. Tsai, W.-J.; Tsai, H.-Y.; Kuo, L.-Y.; Lin, Y.-S.; Chen, B.-Y.; Lin, W.-H.; Shen, S.-L.; Huang, H.-Y. VE/VCO2 Slope and Functional Capacity in Patients Post-Heart Transplantation. Transplant. Proc. 2018, 50, 2733-2737. [CrossRef]

61. Di Nora, C.; Guidetti, F.; Livi, U.; Antonini-Canterin, F. Role of Cardiac Rehabilitation After Ventricular Assist Device Implantation. Heart Fail. Clin. 2021, 17, 273-278. [CrossRef] 